\title{
Favorable Glycemic Control with Once-Daily Insulin Degludec/Insulin Aspart after Changing from Basal Insulin in Adults with Type 2 Diabetes
}

\author{
Han Na Jang ${ }^{1}$, Ye Seul Yang ${ }^{1}$, Seong Ok Lee ${ }^{1}$, Tae Jung Oh², Bo Kyung Koo ${ }^{3}$, Hye Seung Jung \\ ${ }^{1}$ Division of Endocrinology and Metabolism, Department of Internal Medicine, Seoul National University Hospital, Seoul \\ National University College of Medicine, Seoul; ${ }^{2}$ Division of Endocrinology and Metabolism, Department of Internal Medicine, \\ Seoul National University Bundang Hospital, Seoul National University College of Medicine, Seongnam; ${ }^{3}$ Division of \\ Endocrinology and Metabolism, Department of Internal Medicine, Seoul Metropolitan Government Seoul National University \\ Boramae Medical Center, Seoul National University College of Medicine, Seoul, Korea
}

Background: Conflicting results have been reported on the efficacy of insulin degludec/insulin aspart (IDegAsp) compared to basal insulin in type 2 diabetes. We investigated the effects of changing basal insulin to IDegAsp on glycemic control and sought to identify factors related to those effects.

Methods: In this retrospective study of patients from three referral hospitals, patients with type 2 diabetes using basal insulin with hemoglobin A1c (HbA1c) levels less than 11.0\% were enrolled. Basal insulin was replaced with IDegAsp, and data were analyzed from 3 months before to 3 months after the replacement.

Results: Eighty patients were recruited (52.5\% male; mean age, $67.0 \pm 9.8$ years; mean duration of diabetes, $18.9 \pm 8.5$ years; mean $\mathrm{HbAlc}, 8.7 \% \pm 1.0 \%)$. HbA1c levels increased during 3 months of basal insulin use, but significantly decreased after changing to IDegAsp $(8.28 \% \pm 1.10 \%, P=0.0001)$. The reduction was significant at 6 months in 35 patients whose longer-term data were available. Patients with a measured fasting plasma glucose (m-FPG) lower than their predicted FPG (p-FPG) by regression from $\mathrm{HbA1c}$ showed a significant HbA1c reduction caused by the change to IDegAsp, even without a significantly increased insulin dose. However, patients whose m-FPG was higher than their p-FPG did not experience a significant $\mathrm{HbA1c}$ reduction, despite a significantly increased insulin dose. Furthermore, the HbA1c reduction caused by IDegAsp was significant in patients with low fasting C-peptide levels and high insulin doses.

Conclusion: We observed a significant glucose-lowering effect by replacing basal insulin with IDegAsp, especially in patients with a lower m-FPG than p-FPG.

Keywords: Insulin degludec, insulin aspart drug combination; Diabetes mellitus, type 2; Insulin deficiency; Hyperglycemia; Basal insulin

Received: 17 August 2019, Revised: 12 October 2019,

Accepted: 2 November 2019

Corresponding author: Hye Seung Jung

Department of Internal Medicine, Seoul National University Hospital, Seoul

National University College of Medicine, 101 Daehak-ro, Jongno-gu, Seoul 03080, Korea

Tel: +82-2-2072-0240, Fax: +82-2-764-2199, E-mail: junghs@snu.ac.kr

\section{Copyright $\odot 2019$ Korean Endocrine Society}

This is an Open Access article distributed under the terms of the Creative Commons Attribution Non-Commercial License (http://creativecommons.org/ licenses/by-nc/4.0/) which permits unrestricted non-commercial use, distribution, and reproduction in any medium, provided the original work is properly cited. 


\section{INTRODUCTION}

Type 2 diabetes is characterized by insulin resistance and dysfunction of pancreatic $\beta$-cells [1], and as the duration of diabetes increases, a large number of patients eventually require insulin administration because of insulin insufficiency [2]. They mostly begin to use basal insulin, and if glycemic control is poor with basal insulin, possible options to be considered include adding prandial insulin injections (basal-bolus insulin regimen) or changing to premixed biphasic insulin [3]. The basal-bolus insulin regimen has the advantage of satisfying both mealtime and between-meal insulin demand [4], but has the disadvantage of requiring an increased frequency of insulin administration [5]. Meanwhile, when patients administer premixed biphasic insulin, they may be relatively comfortable regarding the frequency of insulin injections, but the risk of hypoglycemia may be increased because of interactions among the insulin preparation ingredients [6].

Insulin degludec/insulin aspart (IDegAsp), a newly developed insulin composite, allows insulin degludec and insulin aspart to exist independently and stably [7]. In the IDegAsp composite, insulin degludec covers basal insulin demand, and insulin aspart fulfills mealtime insulin demand [8]. Additionally, it was expected that IDegAsp could theoretically regulate blood glucose with fewer hypoglycemic events than premixed biphasic insulin owing to the long duration of action and lower day-to-day variability of insulin degludec [9]. Consistent with this mechanism, it was reported that administrating IDegAsp twice a day controlled blood glucose levels more effectively than administrating premixed biphasic insulin, with fewer hypoglycemic events, in patients with type 2 diabetes [10,11].

However, previous studies comparing basal insulin and oncedaily IDegAsp in patients with type 2 diabetes have shown conflicting results in terms of hemoglobin $\mathrm{A} 1 \mathrm{c}(\mathrm{HbAlc})$ improvements [12]. Hypoglycemic events were even found to be increased by the use of IDegAsp in most studies [13-15]. Therefore, it is necessary to identify the real-world effects of oncedaily IDegAsp. In this multicenter study, we investigated the effects of changing basal insulin to IDegAsp in Koreans with type 2 diabetes, and explored the clinical factors related with those effects.

\section{METHODS}

\section{Study subjects}

We retrospectively analyzed the clinical data of adults with type
2 diabetes who visited endocrinology outpatient clinics at Seoul National University Hospital, Seoul National Bundang Hospital, and Boramae Medical Center. Those who had used basal insulin (insulin glargine-U100, insulin glargine-U300, insulin detemir, and insulin degludec) for at least 4 months with an HbAlc level less than $11.0 \%$, without any changes in their oral hypoglycemic agents, were enrolled. Basal insulin was replaced with once-daily IDegAsp from November 2017 to May 2019, and clinical and laboratory data were collected at 3 months before the replacement, the replacement point (baseline), and 3 months after the replacement. If available, data at 6 months were also collected.

We excluded (1) pregnant patients; (2) patients diagnosed with cardiovascular disease, cancer, or another critical illness within 6 months before the replacement; (3) patients with severe hypertension; and (4) patients receiving treatments or having diseases that may have a significant effect on blood glucose levels, such as glucocorticoids and thyrotoxicosis.

\section{Calculation of gap-fasting plasma glucose}

Predicted fasting plasma glucose (p-FPG) was calculated from a linear regression analysis of $\mathrm{HbAlc}$ and FPG at baseline in this population $[16,17]$.

$$
\begin{aligned}
& \mathrm{p}-\mathrm{FPG}=14.842 \times \mathrm{HbA1} \text { ( }(\%)-4.257, r=0.347, P=0.002 \\
& \text { Gap-FPG }=\text { measured FPG }(\mathrm{m}-\mathrm{FPG})-\mathrm{p}-\mathrm{FPG}
\end{aligned}
$$

\section{Outcomes}

The primary outcome was the change in $\mathrm{HbAlc}$ levels caused by the replacement of basal insulin with once-daily IDegAsp. The secondary outcomes were clinical factors related with the glucose-lowering effects of once-daily IDegAsp.

\section{Statistical analysis}

Continuous variables with a normal distribution were expressed as mean and standard deviation, unless otherwise indicated. The variables before and after IDegAsp use were analyzed by repeated-measures analysis of variance (ANOVA) and the Bonferroni multiple comparison test for post hoc analyses (the Friedman test and Dunn multiple comparison test for post hoc analyses were used for analyzing non-normally distributed continuous variables). The variables among subgroups were analyzed by one-way ANOVA. Correlations between $\mathrm{HbAlc}$ reduction and basal characteristics were analyzed using the Pearson correlation test. $P$ values $<0.05$ were considered to indicate statistical significance. SPSS for Windows version 25.0 (IBM Co., Armonk, NY, USA) and Prism 5 for Windows version 5.03 
(GraphPad Software, San Diego, CA, USA) were used for the statistical analysis.

\section{Ethical statement}

This study was conducted in accordance with the Declaration of Helsinki. The trial protocol was reviewed and approved by the Institutional Review Board of each center (IRB no. H-1903068-1016, no. B-1905/540-406, no. 20190426/30-2019-35/053). The need for patient consent was waived by the IRB since this was a retrospective study, and analyses were performed using de-identified data.

\section{RESULTS}

\section{Changes in FPG and HbA1c}

A total of 80 participants were enrolled in this study, of whom $52.5 \%$ were male. At the time of changing the insulin regimen, their mean age was $67.0 \pm 9.8$ years, their mean body mass index (BMI) was $24.5 \pm 3.8 \mathrm{~kg} / \mathrm{m}^{2}$, the mean duration of diabetes was $18.9 \pm 8.5$ years, their mean $\mathrm{HbAlc}$ level was $8.7 \% \pm 1.0 \%$, their mean FPG was $124.8 \pm 41.5 \mathrm{mg} / \mathrm{dL}$, and their mean C-peptide level was $1.63 \pm 1.37 \mathrm{ng} / \mathrm{mL}$. Their average insulin dose and the insulin dose per body weight were $23.4 \pm 10.7$ IU and

Table 1. Clinical Characteristics of Participants According to Baseline Gap-FPG

\begin{tabular}{|c|c|c|c|c|c|}
\hline \multirow[b]{2}{*}{ Variable } & \multirow[b]{2}{*}{$\begin{array}{l}\text { Total participants } \\
\qquad(n=80)\end{array}$} & \multicolumn{3}{|c|}{ Gap-FPG } & \multirow[b]{2}{*}{$P$ value } \\
\hline & & $\begin{array}{c}<-20 \mathrm{mg} / \mathrm{dL} \\
\quad(n=26)\end{array}$ & $\begin{array}{c}\geq-20 \text { and }<20 \mathrm{mg} / \mathrm{dL} \\
(n=32)\end{array}$ & $\begin{array}{c}\geq 20 \mathrm{mg} / \mathrm{dL} \\
\quad(n=22)\end{array}$ & \\
\hline Male sex & $42(52.5)$ & $12(46.2)$ & $15(46.9)$ & $15(68.2)$ & 0.224 \\
\hline Age, yr & $67.0 \pm 9.8$ & $65.4 \pm 11.4$ & $66.9 \pm 9.80$ & $69.2 \pm 7.5$ & 0.402 \\
\hline BMI, $\mathrm{kg} / \mathrm{m}^{2}$ & $24.5 \pm 3.8(n=70)$ & $24.7 \pm 4.7(n=23)$ & $25.0 \pm 3.7(n=26)$ & $23.7 \pm 2.8(n=21)$ & 0.501 \\
\hline Duration of diabetes, yr & $18.9 \pm 8.5(n=69)$ & $18.8 \pm 7.8(n=25)$ & $17.9 \pm 8.0(n=28)$ & $20.8 \pm 10.4(n=16)$ & 0.560 \\
\hline $\mathrm{HbA} 1 \mathrm{c}, \%$ & $8.7 \pm 1.0$ & $8.7 \pm 0.8$ & $8.6 \pm 0.9$ & $8.8 \pm 1.3$ & 0.878 \\
\hline $\mathrm{FPG}, \mathrm{mg} / \mathrm{dL}$ & $124.8 \pm 41.5$ & $87.0 \pm 11.3$ & $120.4 \pm 18.1$ & $175.7 \pm 36.5$ & $<0.001$ \\
\hline Gap-FPG, mg/dL & $0.0 \pm 38.9$ & $-37.8 \pm 13.1$ & $-3.5 \pm 12.9$ & $49.8 \pm 29.4$ & NA \\
\hline Fasting C-peptide, ng/mL & $1.63 \pm 1.37(n=61)$ & $1.75 \pm 2.00(n=20)$ & $1.35 \pm 0.81(n=23)$ & $1.86 \pm 1.04(n=18)$ & 0.451 \\
\hline Insulin dose, IU & $23.4 \pm 10.7$ & $21.1 \pm 8.5$ & $25.6 \pm 11.8$ & $22.7 \pm 11.0$ & 0.263 \\
\hline Insulin dose, IU/kg & $0.36 \pm 0.14(n=70)$ & $0.33 \pm 0.12(n=23)$ & $0.37 \pm 0.14(n=26)$ & $0.37 \pm 0.16(n=21)$ & 0.585 \\
\hline Total cholesterol, mg/dL & $143.8 \pm 35.1$ & $141.0 \pm 29.4$ & $147.4 \pm 43.6$ & $141.7 \pm 27.7$ & 0.757 \\
\hline $\mathrm{eGFR}, \mathrm{mL} / \mathrm{min} / 1.73 \mathrm{~m}^{2}$ & $73.3 \pm 31.5$ & $71.4 \pm 33.4$ & $81.5 \pm 28.0$ & $63.6 \pm 32.4$ & 0.113 \\
\hline Retinopathy & $49(61.3)$ & $17(65.4)$ & $20(65.5)$ & $12(54.5)$ & 0.732 \\
\hline \multicolumn{6}{|l|}{ Basal insulin } \\
\hline Glargine U-100 & $40(50.0)$ & $13(50.0)$ & $15(46.9)$ & $12(54.5)$ & \\
\hline Degludec & $23(28.8)$ & $7(26.9)$ & $11(34.4)$ & $5(22.7)$ & \\
\hline Glargine U-300, detemir & $17(21.3)$ & $6(23.1)$ & $6(18.8)$ & $5(22.7)$ & 0.914 \\
\hline \multicolumn{6}{|l|}{$\mathrm{OAD}$} \\
\hline Metformin & $65(81.3)$ & $22(84.6)$ & $27(84.4)$ & $16(72.7)$ & 0.485 \\
\hline DPP4 inhibitors & $44(55.0)$ & $15(57.7)$ & $18(56.3)$ & $11(50.0)$ & 0.853 \\
\hline Sulfonylurea & $39(48.8)$ & $12(46.2)$ & $16(50.0)$ & $11(50.0)$ & 0.949 \\
\hline Others & $8(10.0)$ & $2(7.7)$ & $2(6.3)$ & $4(18.2)$ & 0.318 \\
\hline \multicolumn{6}{|l|}{ Other medications } \\
\hline Hypertension & $53(66.3)$ & $15(57.7)$ & $22(68.8)$ & $16(72.7)$ & 0.508 \\
\hline Dyslipidemia & $65(81.3)$ & $21(80.8)$ & $27(84.4)$ & $17(77.3)$ & 0.804 \\
\hline
\end{tabular}

Values are expressed as number $(\%)$ or mean \pm standard deviation.

FPG, fasting plasma glucose; gap-FPG, gap between measured FPG and predicted FPG; BMI, body mass index; HbA1c, hemoglobin A1c; NA, not applicable; eGFR, estimated glomerular filtration rate; OAD, oral antidiabetic drug; DPP4, dipeptidyl peptidase IV.

${ }^{a} P$ values for overall differences among the three groups according to gap-FBS, analyzed by one-way analysis of variance and the chi-square test. 
$0.36 \pm 0.14 \mathrm{IU} / \mathrm{kg}$, respectively. Half of the patients were using insulin glargine U-100 as basal insulin (Table 1).

We compared insulin doses and glycemic control at 3 months before the replacement, at the time of the replacement (baseline), and at 3 months after the replacement. Before changing to once-daily IDegAsp, although the basal insulin dose increased statistically significantly (from $0.34 \pm 0.13$ to $0.36 \pm 0.14 \mathrm{IU} / \mathrm{kg}$, $P=0.0005$ ), $\mathrm{HbA} 1 \mathrm{c}$ increased significantly (from $8.5 \% \pm 1.0 \%$ to $8.7 \% \pm 1.0 \%, P=0.0080$ ). However, HbA1c decreased significantly after changing to once-daily IDegAsp (from $8.7 \% \pm$ $1.0 \%$ to $8.3 \% \pm 1.1 \%, P=0.0001)$ accompanied with a dose increment (from $0.36 \pm 0.14$ to $0.39 \pm 0.15 \mathrm{IU} / \mathrm{kg}, P<0.0001$ ) (Fig. 1A). There was no significant change in FPG among the three time points.

When we conducted a sub-analysis of 35 patients whose clinical data were available as far as 6 months after the replacement, there was no significant reduction in $\mathrm{HbAlc}$ levels (from $8.4 \% \pm 1.0 \%$ to $8.6 \% \pm 1.0 \%$ ), even though there was a significant increase in the basal insulin dose during the 3 months before the replacement (from $0.34 \pm 0.15$ to $0.35 \pm 0.15 \mathrm{IU} / \mathrm{kg}$, $P=0.0318$ ). However, there was a significant decrease in $\mathrm{HbAlc}$ levels at 6 months after the replacement of basal insulin with IDegAsp (from $8.6 \% \pm 1.0 \%$ to $8.2 \% \pm 1.1 \%, P=0.0342$ ), accompanied by an increased dose (from $0.35 \pm 0.15$ to $0.39 \pm$ $0.17 \mathrm{IU} / \mathrm{kg}, P=0.0053$ ) (Fig. 1B).

\section{Different glycemic effects of IDegAsp according to gap- FPG}

Theoretically, IDegAsp would be advantageous compared to basal insulin in patients with marked postprandial hyperglyce- mia. We presumed that those who demonstrated a low FPG relative to their HbAlc might have this characteristic. Therefore, we calculated p-FPG and gap-FPG as described above.

Next, we divided the patients according to gap-FPG into three groups: low (gap-FPG $<-20 \mathrm{mg} / \mathrm{dL}$ ), intermediate $(-20 \leq$ gapFPG $<20 \mathrm{mg} / \mathrm{dL}$ ), and high (gap-FPG $\geq 20 \mathrm{mg} / \mathrm{dL}$ ). Except for the FPG, the clinical characteristics at baseline were not statistically significantly different among these three groups (Table 1). In the low gap-FPG group, HbA1c levels increased significantly before the change to IDegAsp. However, the change to IDegAsp without a significant dose increment resulted in a significant decrease in HbAlc levels (Table 2). In the intermediate group, although a significant basal insulin increment did not reduce $\mathrm{HbA1c}$ levels, the change to IDegAsp accompanied by a significant dose increment decreased $\mathrm{HbAlc}$ levels significantly. However, there was no significant change in HbAlc levels after changing to once-daily IDegAsp in the high gap-FPG group, even with a significant increase in the insulin dose.

\section{Different glycemic effects of IDegAsp according to insulin deficiency}

To evaluate the effect of IDegAsp by endogenous insulin secretion, 54 patients were divided into three groups according to fasting C-peptide levels, after excluding patients with an estimated glomerular filtration rate (eGFR) of less than $45 \mathrm{~mL} / \mathrm{min} /$ $1.73 \mathrm{~m}^{2}$ : low (C-peptide $\left.<0.7 \mathrm{ng} / \mathrm{mL}\right)$, intermediate $(0.7 \leq \mathrm{C}$ peptide $<1.8 \mathrm{ng} / \mathrm{mL}$ ), and high (C-peptide $\geq 1.8 \mathrm{ng} / \mathrm{mL}$ ). There were no significant differences in baseline characteristics except for BMI and FPG among these three groups, and these baseline characteristics were not correlated with $\mathrm{HbAlc}$ reduction after
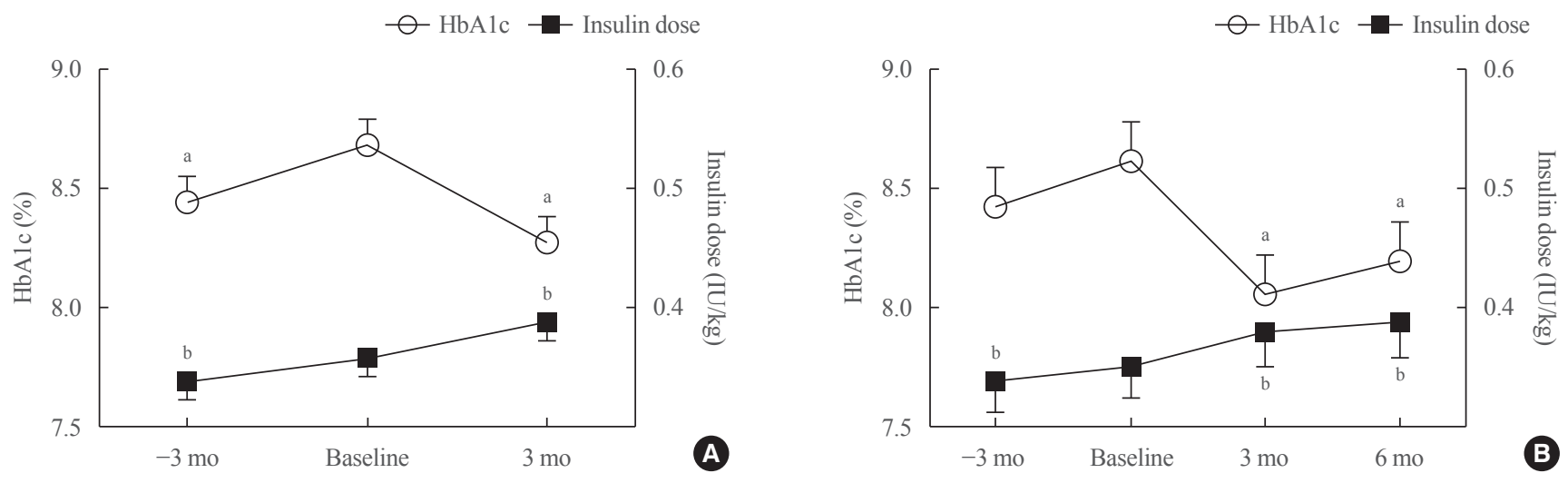

Fig. 1. Changes in hemoglobin A1c (HbA1c) levels and the insulin dose before and after the replacement of basal insulin with once-daily insulin degludec/insulin aspart (IDegAsp). (A) Changes up to 3 months after the replacement of basal insulin with once-daily IDegAsp. (B) Changes up to 6 months after the replacement of basal insulin with once-daily IDegAsp $(n=35) .{ }^{\mathrm{a}, \mathrm{b}} P<0.05$ vs. baseline by post hoc analyses (the Bonferroni multiple comparison test and the Dunn multiple comparison test). 
Table 2. Comparison of Insulin Doses and HbA1c Levels before and after the Change to Once-Daily IDegAsp from Basal Insulin According to Gap-FPG

\begin{tabular}{|c|c|c|c|c|}
\hline Variable & $-3 \mathrm{mo}$ & Baseline & $3 \mathrm{mo}$ & $P$ value \\
\hline \multicolumn{5}{|c|}{ Low (gap-FPG $<-20$ mg/dL) } \\
\hline Insulin, IU/kg & $0.32 \pm 0.12$ & $0.33 \pm 0.12$ & $0.35 \pm 0.11$ & 0.001 \\
\hline $\mathrm{HbAlc}, \%$ & $8.3 \pm 0.9^{\mathrm{b}}$ & $8.7 \pm 0.8$ & $8.3 \pm 0.9^{b}$ & 0.021 \\
\hline \multicolumn{5}{|c|}{ Intermediate $(-20 \leq$ gap-FPG $<20 \mathrm{mg} / \mathrm{dL})$} \\
\hline Insulin, IU/kg & $0.34 \pm 0.13^{b}$ & $0.37 \pm 0.14$ & $0.39 \pm 0.16^{b}$ & $<0.001$ \\
\hline HbA1c, $\%$ & $8.4 \pm 0.8$ & $8.6 \pm 0.9$ & $8.2 \pm 1.0^{\mathrm{b}}$ & 0.018 \\
\hline \multicolumn{5}{|c|}{ High (gap-FPG $\geq 20$ mg/dL) } \\
\hline Insulin, IU/kg & $0.35 \pm 0.15$ & $0.37 \pm 0.16$ & $0.41 \pm 0.17^{\mathrm{b}}$ & 0.002 \\
\hline $\mathrm{HbA} 1 \mathrm{c}, \%$ & $8.6 \pm 1.3$ & $8.8 \pm 1.3$ & $8.3 \pm 1.5$ & 0.059 \\
\hline
\end{tabular}

Values are expressed as mean \pm standard deviation.

HbAlc, hemoglobin A1c; IDegAsp, insulin degludec/insulin aspart; gap-FPG, gap between measured fasting plasma glucose (FPG) and predicted FPG. ${ }^{a} P$ values for overall differences among the three time points analyzed by repeated-measures analysis of variance; ${ }^{b} P<0.05$ vs. baseline by post hoc analyses (the Bonferroni multiple comparison test).

Table 3. Comparison of Insulin Doses and HbA1c Levels before and after the Change to Once-Daily IDegAsp from Basal Insulin According to Insulin Reservoir

\begin{tabular}{|c|c|c|c|c|}
\hline Variable & $-3 \mathrm{mo}$ & Baseline & $3 \mathrm{mo}$ & $P$ value $^{\mathrm{a}}$ \\
\hline \multicolumn{5}{|c|}{ According to fasting C-peptide levels, $\mathrm{ng} / \mathrm{mL}$} \\
\hline \multicolumn{5}{|c|}{ C-peptide $<0.7(n=17)$} \\
\hline Insulin, IU/kg & $0.38 \pm 0.15$ & $0.39 \pm 0.15$ & $0.41 \pm 0.14$ & 0.019 \\
\hline HbAlc (\%) & $8.5(7.1-10.6)$ & $8.9(7.1-10.2)$ & $8.4(5.6-10.6)^{\mathrm{b}}$ & 0.057 \\
\hline \multicolumn{5}{|c|}{ C-peptide $\geq 0.7$ and $<1.8(n=15)$} \\
\hline Insulin, IU/kg & $0.36 \pm 0.11^{b}$ & $0.39 \pm 0.11$ & $0.43 \pm 0.12^{\mathrm{b}}$ & 0.000 \\
\hline HbAlc, $\%$ & $8.4 \pm 0.9$ & $8.8 \pm 0.9$ & $8.1 \pm 0.7^{\mathrm{b}}$ & 0.003 \\
\hline \multicolumn{5}{|c|}{ C-peptide $\geq 1.8(n=22)$} \\
\hline Insulin, IU/kg & $0.37 \pm 0.13$ & $0.39 \pm 0.14$ & $0.44 \pm 0.16^{b}$ & 0.001 \\
\hline $\mathrm{HbA1c}, \%$ & $8.7 \pm 0.9$ & $8.7 \pm 0.9$ & $8.7 \pm 1.1$ & 0.871 \\
\hline \multicolumn{5}{|c|}{ According to insulin dose, IU/kg } \\
\hline \multicolumn{5}{|c|}{ Insulin dose $>0.52(n=11)$} \\
\hline Insulin, IU/kg & $0.54 \pm 0.07^{b}$ & $0.57 \pm 0.06$ & $0.59 \pm 0.06$ & 0.020 \\
\hline HbAlc, $\%$ & $9.4(7.8-10.1)$ & $9.1(7.8-9.9)$ & $8.6(7.3-10.2)^{b}$ & 0.028 \\
\hline \multicolumn{5}{|c|}{ Insulin dose $>0.35$ and $\leq 0.52(n=19)$} \\
\hline Insulin, IU/kg & $0.38 \pm 0.07^{\mathrm{b}}$ & $0.43 \pm 0.05$ & $0.48 \pm 0.08^{b}$ & 0.000 \\
\hline HbAlc, $\%$ & $8.8 \pm 1.0$ & $9.1 \pm 1.0$ & $8.5 \pm 1.2^{\mathrm{b}}$ & 0.022 \\
\hline \multicolumn{5}{|c|}{ Insulin dose $\leq 0.35(n=26)$} \\
\hline Insulin, IU/kg & $0.25 \pm 0.07$ & $0.25 \pm 0.06$ & $0.28 \pm 0.07^{b}$ & 0.000 \\
\hline HbAlc, $\%$ & $8.3 \pm 0.9$ & $8.5 \pm 0.8$ & $8.4 \pm 1.2$ & 0.510 \\
\hline
\end{tabular}

Values are expressed as mean \pm standard deviation or median (range).

HbA1c, hemoglobin A1c; IDegAsp, insulin degludec/insulin aspart.

${ }^{a} P$ values for overall differences among the three time points analyzed by repeated-measures analysis of variance and the Friedman test; ${ }^{b} P<0.05$ vs. baseline by post hoc analyses (the Bonferroni multiple comparison test and the Dunn multiple comparison test). 
the change to IDegAsp (data not shown). In the low C-peptide group, there was a significant decrease in $\mathrm{HbAlc}$ levels after changing to once-daily IDegAsp, even though there was no significant change in the insulin dose (Table 3). In the intermediate group, although a significant basal insulin increment did not reduce HbA1c levels, the change to IDegAsp accompanied by a significant dose increment decreased $\mathrm{HbAlc}$ levels significantly. However, no significant changes in $\mathrm{HbAlc}$ levels were observed during the study period in the high C-peptide group, despite a significant increase in the insulin dose.

Another indirect index for insulin deficiency may be the insulin dose. We divided 56 patients according to the insulin dose after excluding patients with an eGFR less than $45 \mathrm{~mL} / \mathrm{min} / 1.73 \mathrm{~m}^{2}$ : low (insulin/body weight $\leq 0.35 \mathrm{IU} / \mathrm{kg})$, intermediate $(0.35<$ insulin/body weight $\leq 0.52 \mathrm{IU} / \mathrm{kg}$ ), and high (insulin/body weight $>0.52 \mathrm{IU} / \mathrm{kg}$; maximum, $0.71 \mathrm{IU} / \mathrm{kg}$ ). There were no significant differences in baseline characteristics except for eGFR among the three groups, and eGFR was not correlated with the HbAlc reduction after change to IDegAsp (data not shown). In the high-dose group, a significant increase in basal insulin dose did not reduce $\mathrm{HbA1c}$ levels significantly; howev$\mathrm{er}$, there was a significant decrease in $\mathrm{HbA} 1 \mathrm{c}$ levels after changing to once-daily IDegAsp, even though there was no significant increase in the insulin dose (Table 3). In the intermediate group, although a significant basal insulin increment did not reduce HbAlc levels, the change to IDegAsp accompanied by a significant dose increment decreased $\mathrm{HbA1c}$ levels significantly. However, no significant changes in $\mathrm{HbAlc}$ were observed during the study period in the low-dose group, despite a significant increase in the insulin dose.

\section{Hypoglycemia}

Because this was a retrospective study involving medical record review, hypoglycemia could not be assessed precisely. In nine of the 80 patients, there was a record of increased hypoglycemia after the change to IDegAsp.

\section{DISCUSSION}

In this retrospective study, we found a significant decrease in HbAlc levels after changing to once-daily IDegAsp with a concurrent increase in the dose (by $0.03 \pm 0.01 \mathrm{IU} / \mathrm{kg}, P<0.0001$ ) in patients with type 2 diabetes who had shown poor glycemic control on basal insulin. Indeed, the increase of basal insulin (by $0.02 \pm 0.01 \mathrm{IU} / \mathrm{kg}, P=0.0005$ ) had aggravated their HbA1c levels, indirectly suggesting that once-daily IDegAsp would be more favorable than basal insulin in this population (Fig. 1).

In previous studies comparing once-daily IDegAsp and basal insulin, overall hypoglycemic events were increased by oncedaily IDegAsp, with inconsistent results for blood glucose control [13-15]. Therefore, we presumed that once-daily IDegAsp might be better than basal insulin only in a subset of patients, such as those with marked postprandial hyperglycemia. To identify this assumption, the study participants were divided according to gap-FPG, which is a simple estimate of postprandial hyperglycemia, and the effects of IDegAsp were evaluated in each subgroup. As expected, favorable effects of IDegAsp were clearly present in patients with low gap-FPG, but not in those with high gap-FPG (Table 2). As a result, once-daily IDegAsp seemed to be more favorable than basal insulin in patients with marked postprandial hyperglycemia.

Postprandial hyperglycemia, a form of glycemic variability, can result from severe insulin deficiency [18]. In this study, we used fasting C-peptide and the insulin dose as indicators of insulin deficiency. In general, insulin deficiency is measured using the homeostatic model assessment-B obtained from serum insulin levels, but measurements of insulin levels can be confounded by exogenous insulin unless washout is performed. In addition, since this study had a retrospective design, insulin secretion data from stimulation tests were not available. Therefore, fasting C-peptide was used as a surrogate indicator for insulin secretion because not much other data were available. The maximum insulin dose in this study was $0.7 \mathrm{IU} / \mathrm{kg}$. In addition, the mean duration of diabetes was 19 years. In this context, the insulin dose would be expected to reflect insulin deficiency, rather than insulin resistance, even though the participants were patients with type 2 diabetes. Compatible with this, glycemic effect of IDegAsp was prominent in patients with low fasting Cpeptide levels $(<0.7 \mathrm{ng} / \mathrm{mL})$ or a high insulin dose $(0.52$ to 0.71 $\mathrm{IU} / \mathrm{kg}$ ), while it was not observed in those with high C-peptide levels $(\geq 1.8 \mathrm{ng} / \mathrm{mL})$ or a low insulin dose $(\leq 0.35 \mathrm{IU} / \mathrm{kg})$ (Table $3)$. These observations suggest that once-daily IDegAsp might be especially effective in comparison to basal insulin in insulindeficient patients.

This study has the strength of exploring the real-world effects of replacing basal insulin with once-daily IDegAsp through a multicenter study, and it provides the first evidence that IDegAsp may be superior, especially in patients with high glycemic variability or severe insulin deficiency.

This study has several limitations. Its retrospective design means that patient compliance could not be evaluated, and the actual insulin doses could have been different from the prescrip- 
tions in patients' medical records. Additionally, this was a single-arm study without a control group, and confounding by the placebo effect cannot be excluded. Furthermore, in addition to effectiveness, safety is also an important issue, considering the previous reports of increased hypoglycemia associated with once-daily IDegAsp $[12,15]$. However, hypoglycemia could not be fully evaluated by medical record review. Therefore, a prospective controlled trial is warranted to confirm the favorable effects and safety of once-daily IDegAsp compared to basal insulin in patients with high glycemic variability or severe insulin deficiency.

In conclusion, we observed a significant blood glucose-lowering effect of changing to once-daily IDegAsp from basal insulin in type 2 diabetes patients with poor glycemic control, and the effect seemed to be greater in patients with more severe insulin deficiency and variations in blood glucose levels. If these findings are confirmed by a further controlled study, we could expect to improve blood glucose control without increasing the number of insulin injections by changing to once-daily IDegAsp in a subset of patients whose glycemic control is poor with basal insulin.

\section{CONFLICTS OF INTEREST}

No potential conflict of interest relevant to this article was reported.

\section{AUTHOR CONTRIBUTIONS}

Conception or design: H.S.J. Acquisition, analysis, or interpretation of data: H.N.J., Y.S.Y., S.O.L., T.J.O., B.K.K., H.S.J. Drafting the work or revising: H.N.J., H.S.J. Final approval of the manuscript: H.N.J., Y.S.Y., S.O.L., B.K.K., T.J.O., H.S.J.

\section{ORCID}

Han Na Jang https://orcid.org/0000-0002-6186-2937

Hye Seung Jung https://orcid.org/0000-0002-0221-7049

\section{REFERENCES}

1. Ha KH, Park CY, Jeong IK, Kim HJ, Kim SY, Kim WJ, et al. Clinical characteristics of people with newly diagnosed type 2 diabetes between 2015 and 2016: difference by age and body mass index. Diabetes Metab J 2018;42:137-46.

2. Rudenski AS, Hadden DR, Atkinson AB, Kennedy L, Mat- thews DR, Merrett JD, et al. Natural history of pancreatic islet B-cell function in type 2 diabetes mellitus studied over six years by homeostasis model assessment. Diabet Med 1988;5:36-41.

3. Lee BW, Kim JH, Ko SH, Hur KY, Kim NH, Rhee SY, et al. Insulin therapy for adult patients with type 2 diabetes mellitus: a position statement of the Korean Diabetes Association, 2017. Diabetes Metab J 2017;41:367-73.

4. Lamos EM, Younk LM, Tate DB, Davis SN. Pharmacokinetics and pharmacodynamics of insulin glargine-insulin glulisine basal-bolus and twice-daily premixed analog insulin in type 1 diabetes mellitus patients during three standardized meals. J Clin Transl Endocrinol 2015;3:14-20.

5. Sarbacker GB, Urteaga EM. Adherence to insulin therapy. Diabetes Spectr 2016;29:166-70.

6. Anyanwagu U, Mamza J, Gordon J, Donnelly R, Idris I. Premixed vs basal-bolus insulin regimen in type 2 diabetes: comparison of clinical outcomes from randomized controlled trials and real-world data. Diabet Med 2017;34:172836.

7. Havelund S, Ribel U, Hubalek F, Hoeg-Jensen T, Wahlund PO, Jonassen I. Investigation of the physico-chemical properties that enable co-formulation of basal insulin degludec with fast-acting insulin aspart. Pharm Res 2015;32:2250-8.

8. Haahr H, Fita EG, Heise T. A review of insulin degludec/insulin aspart: pharmacokinetic and pharmacodynamic properties and their implications in clinical use. Clin Pharmacokinet 2017;56:339-54.

9. Heise T, Nosek L, Bottcher SG, Hastrup H, Haahr H. Ultralong-acting insulin degludec has a flat and stable glucoselowering effect in type 2 diabetes. Diabetes Obes Metab 2012;14:944-50.

10. Yang W, Ma J, Hong T, Liu M, Miao H, Peng Y, et al. Efficacy and safety of insulin degludec/insulin aspart versus biphasic insulin aspart 30 in Chinese adults with type 2 diabetes: a phase III, open-label, 2:1 randomized, treat-to-target trial. Diabetes Obes Metab 2019;21:1652-60.

11. Onishi Y, Yamada K, Zacho J, Ekelund J, Iwamoto Y. Insulin degludec/insulin aspart vs biphasic insulin aspart 30 twice daily in Japanese patients with type 2 diabetes: a randomized controlled trial. J Diabetes Investig 2017;8:210-7.

12. Kumar S, Jang HC, Demirag NG, Skjoth TV, Endahl L, Bode B. Efficacy and safety of once-daily insulin degludec/ insulin aspart compared with once-daily insulin glargine in participants with type 2 diabetes: a randomized, treat-to-target study. Diabet Med 2017;34:180-8. 
13. Onishi Y, Ono Y, Rabol R, Endahl L, Nakamura S. Superior glycaemic control with once-daily insulin degludec/insulin aspart versus insulin glargine in Japanese adults with type 2 diabetes inadequately controlled with oral drugs: a randomized, controlled phase 3 trial. Diabetes Obes Metab 2013;15: 826-32.

14. Liebl A, Davidson J, Mersebach H, Dykiel P, Tack CJ, Heise T. A novel insulin combination of insulin degludec and insulin aspart achieves a more stable overnight glucose profile than insulin glargine: results from continuous glucose monitoring in a proof-of-concept trial. J Diabetes Sci Technol 2013;7:1328-36.

15. Kumar A, Franek E, Wise J, Niemeyer M, Mersebach H, Simo R. Efficacy and safety of once-daily insulin degludec/ insulin aspart versus insulin glargine (U100) for 52 weeks in insulin-naive patients with type 2 diabetes: a randomized controlled trial. PLoS One 2016;11:e0163350.

16. Rohlfing CL, Wiedmeyer HM, Little RR, England JD, Tennill A, Goldstein DE. Defining the relationship between plasma glucose and $\mathrm{HbA}(1 \mathrm{c})$ : analysis of glucose profiles and $\mathrm{HbA}(1 \mathrm{c})$ in the Diabetes Control and Complications Trial. Diabetes Care 2002;25:275-8.

17. Ahn CH, Min SH, Lee DH, Oh TJ, Kim KM, Moon JH, et al. Hemoglobin glycation index is associated with cardiovascular diseases in people with impaired glucose metabolism. J Clin Endocrinol Metab 2017;102:2905-13.

18. Rizza RA. Pathogenesis of fasting and postprandial hyperglycemia in type 2 diabetes: implications for therapy. Diabetes 2010;59:2697-707. 